\title{
Analysis of Financial Products of Capital Market in Bangladesh: Present Status and Future Development
}

\author{
Mohammad Shahidul Islam ${ }^{1}$ \& Shama Jahan ${ }^{1}$ \\ ${ }^{1}$ School of Business, University of Information Technology and Sciences (UITS), Bangladesh \\ Correspondence: Mohammad Shahidul Islam, Director, MBA Program, UITS, 40/1, Jakir Hossain Road, \\ Khulshi, Chittagong, Bangladesh. E-mail: shahidulislam28@yahoo.com
}

Received: April 18, 2012 Accepted: June 4, 2012 Online Published: September 10, 2012

doi:10.5539/ijms.v4n5p119 URL: http://dx.doi.org/10.5539/ijms.v4n5p119

\begin{abstract}
The performance of existing financial products is an important issue in the capital market to increase the new products for reducing the risk of dependency on common stocks. The research aims are to evaluate the growth and development of existing financial instruments and to recommend for introducing new financial instruments in the capital market of Bangladesh. The data are taken from the Dhaka stock exchange for the year 1977 to 2010 for interpretation of development and the data from 2003 to 2010 are taken for analysis and hypothesis test. There are only five products traded including three types of bonds. The average growth rate of market capitalization of common stocks, treasury bonds, mutual funds, corporate bonds \& debentures are $71.02 \%$, $124.74 \%, 99.85 \%$ and $105.41 \%$ respectively. The growth of market capitalization of all products is high. There is lot of scope in the market for absorbing the new products. The share of common stocks, treasury bond, corporate bond, debentures, mutual funds to total market capitalizations are $87.73 \%, 12.25 \%, 0.24 \%, 0.17 \%$ and $0.83 \%$ respectively. The market is common stock based. The corporate bond market is very small. So, there should be increased new financial instruments in the capital market to reduce the dependency on share only. The proposed financial instruments are various types of preferred stock, bond, SWAP, option, futures, and forwards as recommendation.
\end{abstract}

Keywords: financial products, capital market, market capitalization, option, swap

\section{Introduction}

The capital market is one of the driving forces of an economy. Capital market is the institution that provides a channel for the borrowing and lending of long-term funds for more than one year. It is designed to finance long term investments by business, governments, and households. Capital market consists of two segments: securities segment and non-securities segment. The securities segment is concerned with the process by which firm distributes securities to the public through the primary market and then those securities are traded in the secondary markets. The non securities segments are those where banks and other financial institution provide the long term loan. In the world capital market there are many financial instruments such as-Forward, Futures, Option: Put option, Call option, Spread, Straddle, Strip, Multi-period option: Interest Rate Caps, Floor, Collar, Compound option, Swaps- Commodity Swaps, Interest Rate swaps, Currency Swaps, Variants, Hybrid securities, Synthetic Securities, Zero coupon Bond, Repo, Reserve Repo, Junk bond, Floating rate Preferred Stock, Equity warrant, Putt able common Stock.

The existing instruments of the capital market of Bangladesh are Shares, debentures, mutual fund, and Treasury Bond: 5-year,10-year,15-year,20-year, NSD Certificate (3year\&5year), REPO and REVERSE REPO,US Dollar Premium bond, US dollar investment bond, Wages Earners Development bond in the capital market of Bangladesh.

Like in any other countries, a well developed tradable bond market is critical to ensure stability and efficiency of the financial market in Bangladesh. An efficient bond market is important for managing public debt and bank liquidity and for efficient conduct of monetary policy. So far the bond market has played a limited role in the economy. The country's financial sector is dominated by the commercial banks. 
Thus the debt market in Bangladesh is characterized by excessive reliance on bank deposits, government dominated debt instruments, non- existent corporate bond, high and risk free interest rates, absences of market based yield curve, primary auctions based activity, lack of product variation.

Now, 31 FIs (Financial Institutions) are operating in Bangladesh while the maiden one was established in 1981. Out of the total, 2 is fully government owned, 1 is the subsidiary of a SOCB, 13 were initiated by private domestic initiative and 15 were commenced by joint venture initiative.

\section{Literature Review}

Bangladesh Enterprise Institute (2003), conducted detail research on Improving the Investment Climate in Bangladesh under World Bank. Bangladesh firms tend to have reasonable access to formal finance compared to other low-income countries. In 2001 credit to the private sector amounted to about 27 percent of GDP in Bangladesh. Although this ratio was lower than those in some counties in the region, it compares favorably with the average for low income countries (24 percent of GDP). It was only fractionally lower than the ratios in India (29 percent) and Pakistan (28) percent despite their higher per capita income. Other measures confirm this assessment of finance in Bangladesh. For example, nearly 66 percent of their investment capital, on average, came from retained earnings, while about 30 percent of working and investment capital came from banks. Consider national level data on nonperforming loans. Some estimates put the share of nonperforming industrial loans at around 40 percent. Since banks will have to provision for non performing loans, the large number of such loans could ultimately increase the cost of capital to entrepreneurs. The problems of financial climate are poor access to credit and high cost of borrowing. For solving these, development of secondary market for debt market and enhancement the enforcement authority and institutional capacity of the Securities and Exchange Commission are recommended. (World Bank, (2003), Washington).

B. McGuire, Paul \& John D. Conroy, (2002), conducted research on Fostering Financial Innovation for the poor. Considering financial innovation in terms of this hierarchy helps our understanding of the respective roles of policy direction (as embodied in the legal and regulatory framework) and of market forces (as seen in the behavior of actors in the financial marketplace). The policy decisions of governments, monetary authorities and regulators may effect change and stimulate innovation within all four domains. However, the top (i.e. systemic) level is where policy exerts its greatest and potentially most fruitful influence on innovation. By contrast, market forces operate with increasing influence at the successive lower levels, within 'rules of the game' determined primarily in the systemic domain.

Bepari, M. Khokon (2008) conducted research on Bangladesh Stock Market Growing? Key indicators based Assessment. This paper focuses on the growth of Bangladesh stock market over time. The market trends in terms of market capitalization, market liquidity, market concentration, number of listings, volatility in the market index and foreign portfolio investment were considered. The study finds that key indicators are significantly correlated. Stock market growth index is constructed considering market capitalization ratio; turn over ratio, value traded to GDP ratio and volatility in market index. The findings of the study suggest that although Bangladesh stock market is growing over time, the growth has not yet assumed any stable and obvious trend. It is concluded that Bangladesh stock market is still at an early stage of its growth path with a small market size relative to GDP and is characterized by poor liquidity and high market concentration.

Jahur, (2009) conducted study on bond market development of Bangladesh. The poor stage of bond market in Bangladesh can be attributed to some important factors such as risk \& return factor, liquidity \& government policy related factor, issue management factor and investment policy factor in order of magnitudes.

Rahman and Moazzem (2011) studied on 'Capital Market of Bangladesh: Volatility in the Dhaka Stock Exchange (DSE) and Role of Regulators'. Over the last few years, the capital market of Bangladesh has witnessed a haughty growth which is not in line of development in the real sector of the economy. Although, the Securities and Exchange Commission (SEC) of Bangladesh has tried to correct the irregular behavior observed in the market, very often it is argued that lack of proper and firm decisions from the regulator's side has contributed to make the market more unstable rather than to reduce it. The paper attempts to identify the casual relationship between the observed volatility in the country's major bourses namely the Dhaka Stock Exchange (DSE) and the regulatory decisions taken by the SEC empirically. Using Vector Auto-regressive (VAR), statistically highly significant relationship was found between decisions taken by the regulatory authority and market volatility, although the direction of causality is in reverse order than theoretically and empirically expected.

Ross LEVINEAND SARAZERVOS (2012) studied on 'Stock Markets, Banks, and Economic Growth. Do well-functioning stock markets and banks promote long-run economic growth?' This paper shows that stock 
market liquidity and banking development both positively predict growth, capital accumulation, and productivity improvements when entered together in regressions, even after controlling for economic and political factors. The results are consistent with the views that financial markets provide important services for growth, and that stock markets provide different services from banks. The paper also finds that stock market size, volatility, and international integration are not robustly linked with growth and that none of the financial indicators is closely associated with private saving rates.

Zahid Ahmad, Ather Azim Khan and Anam Tariq (2011) studied on 'Stock market development and economic growth: A comparative study of Pakistan and Bangladesh' .This paper examined the relationship between stock market development and economic growth of two Asian developing countries, that is, Pakistan and Bangladesh, after the liberalization period of 1990s. The relationship measured were in terms of size (market capitalization), liquidity (total value of stocks traded and stock turnover ratio) and volume (total number of companies listed in the stock exchange of each of the country). The study of comparative analysis was done with the help of tables and charts. The econometric results of the study by employing the regression analysis showed that Pakistan stock markets contribute to the economic growth in terms of the large size of its stock market whereas Bangladesh stock market contributes to the economic growth in terms of the liquidity of its stock market Bangladesh economic growth was found to be comparatively better than economic growth of Pakistan. The study revealed that the stock markets in Pakistan and Bangladesh do not play a major role in the economic growth but rather, these financial institutions are the driving forces for the economic growth of the country.

\section{Problem Statement}

The capital market of Bangladesh is small, inefficient and underdeveloped. Of the total financial system, the 'non securities' sector accounts for more than ninety percent of the financial activities in the countries. But this bank based system is virtually on the verge of collapse due to huge nonperforming loans and colossal volume of classified and default loans. So, we are concerned with 'securities segment' because the securities market can develop the national economy. The rate of institutional investment is very low in Bangladesh. The capital market has not yet attained the credibility as an reliable avenue for investment from the side of the general public. The main problems of capital market of Bangladesh are; serious dearth of risk free assets in the secondary market to individual buyers, absence of varied tradable financial Instruments.

The availability of low financial instruments in market, the capital in the market is low comparatively to the developed country and the investors - both institutions and individual are not attracted to invest in capital market in Bangladesh. Introduction of new instruments of finances will provide the opportunities to the companies for getting required fund at lower cost. The introduction of new financing sources will increase the investor's participation in the future offering of companies. This will raise more funds. The research aims are to evaluate the growth and development of existing financial instruments and to recommend for introducing new financial instruments in the capital market of Bangladesh. The traditional instruments are not attractive to the investors. So, it is assumed that new instruments will increase the attraction of investors and volume of capital market and will reduce the dependency on bank based credit.

\section{Methodology}

\subsection{Objectives}

1) To evaluate the growth and development of existing financial instruments in the capital market of Bangladesh.

2) To recommend policies for introducing new financial instruments in the capital market of Bangladesh.

\subsection{Collection of Data}

- The primary data were colleted from the interview with the executives of DSE, CSE, BB (Bangladesh Bank), BSB(Bangladesh Shilpo Bank), ICB(Investment Corporation of Bangladesh), prospective investors, stockbrokers, government officials, and other professionals.

- Secondary data were collected from the following Sources: Publications of Securities and Exchange Commission, Dhaka stock Exchange (DSE) Chittagong Stock Exchange (CSE), Stock market Report on Newspaper, Bangladesh Bank, Bangladesh Bureau of Statistics, Bangladesh Economic Review, Books and Journal, Internet Website.

\subsection{Sample Design}

The data are taken from the Dhaka stock exchange for the year 1977 to 2010 for interpretation of development and the data from 2003 to 2010 are taken for analysis and hypothesis test. 


\subsection{Analysis of Data}

Both qualitative and quantitative analysis will be conducted in the research. Numeric data are analyzed with statistical tools and hypothesis tests are done.

\section{Analysis and Result}

\subsection{Product Development}

Historically, DSE started trading activities in 1976 with only 9 companies. In 1977, the ICB was established in order to give institutional support to the stock exchange. In 1979, the first ICB unit Fund came to the market. The SEC (Securities and Exchange commission) is established in 1993 and CSE was established in 1995. The Central depository system was introduced in 2004. The debenture, Treasury bond, corporate bond came to market in 1987, 2005, 2007 respectively.

\subsubsection{No. of Products}

Now, only five categories of products are traded in the market. These are common share, mutual fund, debenture, Treasury bond, and corporate bond which were introduced in the market in 1977, 1980,1987,2005,2007 respectively.

The corporate bond and debenture market is regulated by the SEC although the market is small. Fixed income securities first came into existence in 1987 with the floatation of debenture by two companies. As on November, 2011, only eight debentures exist in the Dhaka stock exchange. No new debenture was issued after 1999. Besides these, ten debentures already went to maturity.

The corporate bond market is not mentionable feature. Only three corporate bonds are trading in the capital market. First corporate bond is floated in 2007 by the Islami bank Bangladesh limited named as IBBL Mudaraba perpetual bond. Then in 2010, ACI zero coupon bond is introduced in the market.

The primary market of government securities is regulated by the ministry of finance and Bangladesh bank. The government securities are traded in two places -over the counter segment and the organized segment at the stock exchange. The CDBL (Central Depository Bangladesh Limited) provides the depository function for all securities including government securities and corporate bond and debentures. The OTC (over the counter ) segment of the secondary market in the government securities is regulated by Bangladesh Bank while the stock exchange traded segment is regulated by Securities and Exchange Commission (SEC). Primary dealer of government securities are regulated by Bangladesh Bank. Trading of government treasury bonds stated in December 2005 at DSE. As in November 2011, 221 treasury bonds are traded in the market with the name of 5-years Treasury bond, 10-years Treasury bond, 15-years' treasury bonds, and 20-years' Treasury bond.

The common stocks are traded in DSE and CSE. The Dhaka stock exchange started it operation in 1977 with only 9 companies' share capital. Presently as on November 2011, the numbers of common share are 232 in DSE which are gradually increased. The numbers of companies issued share are 192,234,247,218 in 1995, 2000, 2005, and 2010 respectively.

The Dhaka stock exchange introduced Mutual funds operation in 1980.Now, as on November 2011, the numbers of Mutual funds share are 37 in DSE which are gradually increased. The numbers of Mutual funds are $1,3,9,10,15$ in 1980, 1985, 1998, 2000, and 2005 respectively.

\subsection{Market Development}

\subsubsection{Growth and Development of Corporate bond and Government Bond}

\section{Debenture}

Table 1. Corporate bond and debenture

\begin{tabular}{|c|c|c|c|c|c|c|c|c|c|}
\hline Year & 2003 & 2004 & 2005 & 2006 & 2007 & 2008 & 2009 & 2010 & $\mathrm{x}$ \\
\hline $\begin{array}{l}\text { No. of corporate bond } \\
\text { and debentures }\end{array}$ & 8 & 8 & 8 & 8 & 9 & 9 & 9 & 10 & \\
\hline $\begin{array}{l}\text { No. of unit of corporate } \\
\text { bond and debentures }(\mathrm{ml})\end{array}$ & 0.41 & 0.41 & 0.41 & 0.41 & 3.41 & 3.41 & 3.41 & 4.75 & \\
\hline $\begin{array}{l}\text { Issued capital of } \\
\text { corporate bond and } \\
\text { debentures }(\mathrm{ml})\end{array}$ & 289 & 140 & 140 & 140 & 3140 & 3140 & 3140 & 4476 & \\
\hline
\end{tabular}




\begin{tabular}{|c|c|c|c|c|c|c|c|c|c|}
\hline $\begin{array}{l}\text { Growth of Issued capital } \\
\text { of corporate bond and } \\
\text { debentures }(\mathrm{ml})\end{array}$ & $\begin{array}{l}\text { year to } \\
\text { year } \\
\text { growth }\end{array}$ & 48.44 & 0.00 & 0.00 & 2142.86 & 0.00 & 0.00 & 42.55 & \\
\hline $\begin{array}{l}\text { Market } \\
\text { capitalization-Corporate } \\
\text { bond }\end{array}$ & & & & & 4165 & 2764 & 2969 & 3922 & \\
\hline $\begin{array}{l}\text { Value of } \\
\text { debentures(Market } \\
\text { capitalization) }\end{array}$ & 517.47 & 517.47 & 575.696 & 576 & 576 & 576 & 576 & 576 & \\
\hline $\begin{array}{l}\text { Total market } \\
\text { capitalization of } \\
\text { corporate bond and } \\
\text { debentures }\end{array}$ & 517.47 & 517.47 & 575.696 & 576. & 4741 & 3340 & 3545 & 4498 & 1475.13 \\
\hline $\begin{array}{l}\text { Growth of total market } \\
\text { capitalization of } \\
\text { corporate bond and } \\
\text { debentures }\end{array}$ & $\begin{array}{l}\text { base } \\
\text { year } \\
2003\end{array}$ & 0 & 11.25 & 11.31 & 816.19 & 545.45 & 585.06 & 769.23 & \\
\hline $\begin{array}{l}\text { Growth of total market } \\
\text { capitalization of } \\
\text { corporate bond and } \\
\text { debentures }\end{array}$ & $\begin{array}{l}\text { year to } \\
\text { year } \\
\text { growth }\end{array}$ & 0 & 11.25 & 0.05 & 723.09 & -29.55 & 6.14 & 26.88 & 105.41 \\
\hline $\begin{array}{l}\text { Share of debentures to } \\
\text { total market } \\
\text { capitalization( } \%)\end{array}$ & 0.53 & 0.23 & 0.25 & 0.18 & 0.08 & 0.05 & 0.03 & 0.0002 & 0.17 \\
\hline $\begin{array}{l}\text { Share of Corporate bond } \\
\text { to total market } \\
\text { capitalization( } \%)\end{array}$ & & & & & 0.55 & 0.26 & 0.16 & 0.001 & 0.24 \\
\hline $\begin{array}{l}\text { Total share of corporate } \\
\text { bond and debentures }\end{array}$ & 0.53 & 0.23 & 0.25 & 0.18 & 0.63 & 0.31 & 0.19 & 0.0012 & 0.29 \\
\hline $\begin{array}{l}\text { Growth of Total share of } \\
\text { corporate bond and } \\
\text { debentures }\end{array}$ & $\begin{array}{l}\text { year to } \\
\text { year } \\
\text { growth }\end{array}$ & -56.60 & 6.96 & -27.64 & 252.81 & -50.00 & -40.45 & -99.36 & -2.04 \\
\hline $\begin{array}{l}\text { Growth of Total share of } \\
\text { corporate bond and } \\
\text { debentures }\end{array}$ & $\begin{array}{l}\text { base } \\
\text { year } \\
2003\end{array}$ & -56.60 & -53.58 & -66.42 & 18.49 & -40.75 & -64.72 & -99.77 & \\
\hline
\end{tabular}

Source: Dhaka Stock Exchange. www.dsebd.org/

Now we shall see the growth of the debenture market. From the table-1, it is shown that only 8 number of debenture with the 409000 units exist in the market. Average market capitalization is tk.55, 85, 90,566. The total value (market capitalization), tk.576000000 continues for last five years. The average growth of debenture (market capitalization) is $1.88 \%$ and the growth rate is steady over the period. The share of debenture to total market capitalization is decreasing continuously. The average market share is only $0.13 \%$. The growth rate of debenture to total capitalization is decreasing which is $-34.66 \%$ (average).

So, finally, it is said that there is no remarkable growth in the debenture and the market share is very low.

\section{Corporate bond}

From the table-1, it is shown that the total units of corporate bond is 4.34 million market capitalization is tk. 3812 million in 2010 . The average growth rate is $8.43 \%$. The share of corporate bond to total capitalization is reducing continuously. The average market share is $0.226 \%$ which is insignificant to total capitalization. The growth rate of share to total capital is negative. The average growth rate of corporate bond to total capitalization is $-39.54 \%$. So, finally, we can tell from the appendix, the corporate bond market is very small. 


\section{Government bond}

Table 2. Government bond

\begin{tabular}{|c|c|c|c|c|c|c|c|c|c|c|c|c|c|c|c|c|}
\hline & & & 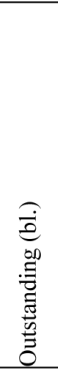 & & & & & & & 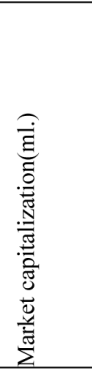 & 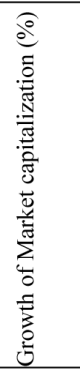 & 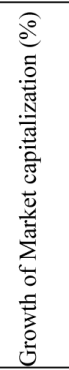 & 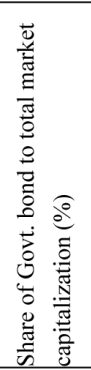 & 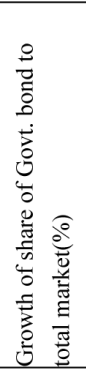 & 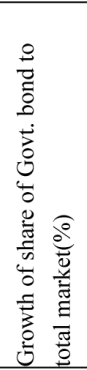 & 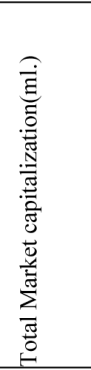 \\
\hline Year & $\begin{array}{l}\text { No. of } \\
\text { treasury } \\
\text { bond }\end{array}$ & $\begin{array}{l}\text { No. of } \\
\text { unit of } \\
\text { treasury } \\
\text { bond } \\
\text { (ml) }\end{array}$ & $\begin{array}{l}5- \\
\text { year }\end{array}$ & $\begin{array}{l}10- \\
\text { year }\end{array}$ & $\begin{array}{l}15- \\
\text { year }\end{array}$ & $\begin{array}{l}20- \\
\text { year }\end{array}$ & total & Growth & Growth & & & & & & & \\
\hline 2003 & & & 0.2 & 0.1 & & & 0.3 & $\begin{array}{l}\text { base year } \\
2003\end{array}$ & $\begin{array}{l}\text { year to } \\
\text { year } \\
\text { growth }\end{array}$ & & $\begin{array}{l}\text { base year } \\
2003\end{array}$ & $\begin{array}{l}\text { year to } \\
\text { year } \\
\text { growth }\end{array}$ & & $\begin{array}{l}\text { base } \\
\text { year } \\
2003\end{array}$ & $\begin{array}{l}\text { year to } \\
\text { year } \\
\text { growth }\end{array}$ & 97586.61 \\
\hline 2004 & & & 6.7 & 3.4 & & & 10.1 & 3266.67 & 32666.67 & & & & & & & 224922.74 \\
\hline 2005 & 18 & 0.13 & 9.5 & 6.9 & & & 16.4 & 5366.67 & 62.38 & 11588.64 & & & 4.96 & & & 233542.94 \\
\hline 2006 & 34 & 0.45 & 28.5 & 32.6 & & & 61.1 & 20266.67 & 272.56 & 44825 & 286.80 & 286.80 & 13.86 & 179.32 & 179.32 & 323368 \\
\hline 2007 & 61 & 1.21 & 62.4 & 72.4 & 6 & 3 & 143.8 & 47833.33 & 135.35 & 122403 & 956.23 & 173.07 & 16.23 & 227.09 & 17.10 & 753955 \\
\hline 2008 & 111 & 2.42 & 102.4 & 120.3 & 21 & 13.5 & 257.2 & 85633.33 & 78.86 & 243403 & 2000.36 & 98.85 & 22.97 & 362.92 & 41.53 & 1059530 \\
\hline 2009 & 151 & 3.56 & 144.7 & 164.8 & 36.8 & 26.6 & 372.9 & 124200.0 & 44.98 & 357313. & 2983.30 & 46.80 & 18.93 & 281.50 & -17.59 & 1887177 \\
\hline 2010 & 186 & 4.2 & & & & & 20 & & & 422213. & 3543.34 & 18.16 & 0.12 & -97.58 & -99.37 & 3471109 \\
\hline
\end{tabular}

Source: Dhaka Stock Exchange. www.dsebd.org/

From the table-2, the total outstanding of Treasury bond is Tk.372.9 billion in 2009 and the market capitalization is Tk. 357313 million in 2009. The average market capitalization is tk. 88826.77 million. The growth rate of market capitalization is decreasing trend. The share of government bond to total market capitalization is 18.93 percent in 2009 and the average share of government bond to total capital is $13.715 \%$. The growth of share of government to total market capitalization is slightly increasing.

5.2.2 Growth and Development of Share

Table 3. Common shares

\begin{tabular}{|c|c|c|c|c|c|c|c|c|c|c|c|c|c|c|}
\hline$\underset{\check{z}}{\ddot{z}}$ & 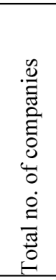 & 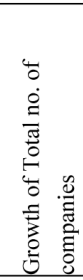 & 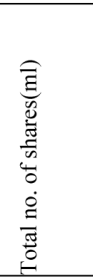 & 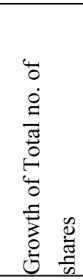 & 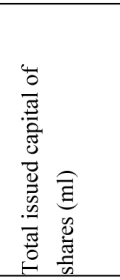 & 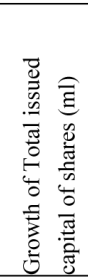 & 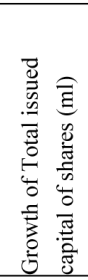 & 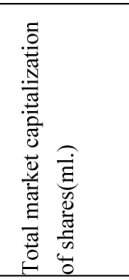 & 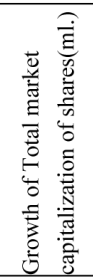 & 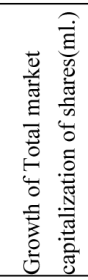 & 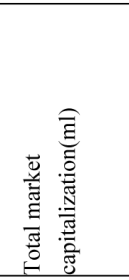 & 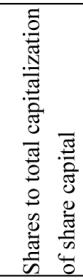 & 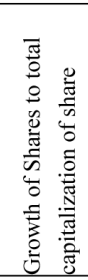 & 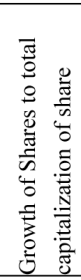 \\
\hline 2003 & 248 & & 1077.92 & & 45370.46 & $\begin{array}{l}\text { base } \\
\text { year } \\
2003\end{array}$ & $\begin{array}{l}\text { year to } \\
\text { year } \\
\text { growth }\end{array}$ & 96405.54 & $\begin{array}{l}\text { base } \\
\text { year } \\
2003\end{array}$ & $\begin{array}{l}\text { year to } \\
\text { year } \\
\text { growth }\end{array}$ & 97586.61 & 98.79 & $\begin{array}{l}\text { year to } \\
\text { year } \\
\text { growth }\end{array}$ & $\begin{array}{l}\text { base } \\
\text { year } \\
2003\end{array}$ \\
\hline 2004 & 237 & -4.44 & 1113.91 & 3.34 & 48996.41 & 7.99 & 7.99 & 223359.07 & 131.69 & 131.69 & 224922.74 & 99.30 & 0.52 & 0.52 \\
\hline 2005 & 247 & 4.22 & 1227.02 & 10.15 & 55631.30 & 22.62 & 13.54 & 219857.20 & 128.05 & -1.57 & 233542.94 & 94.14 & -5.20 & -4.71 \\
\hline 2006 & 255 & 3.24 & 1546.05 & 26.00 & 71745.00 & 58.13 & 28.97 & 276429.00 & 186.74 & 25.73 & 323368.00 & 85.48 & -9.19 & -13.47 \\
\hline 2007 & 266 & 4.31 & 1886 & 21.99 & 88063.00 & 94.10 & 22.74 & 621579.00 & 544.75 & 124.86 & 753955.00 & 82.44 & -3.56 & -16.55 \\
\hline 2008 & 276 & 3.76 & 2428 & 28.74 & 122497.00 & 169.99 & 39.10 & 797009.00 & 726.73 & 28.22 & 1059530.00 & 75.22 & -8.76 & -23.86 \\
\hline 2009 & 236 & -14.49 & 4167 & 71.62 & 156831.00 & 245.67 & 28.03 & 1508255.00 & 1464.49 & 89.24 & 1887177.00 & 79.92 & 6.25 & -19.10 \\
\hline 2010 & 218 & -7.63 & 12335 & 196.02 & 216487.00 & 377.15 & 38.04 & 3001334.00 & 3013.24 & 98.99 & 3471109.00 & 86.47 & 8.19 & -12.47 \\
\hline $\mathrm{x}$ & & & & & & & 25.49 & & & 71.02 & & 87.72 & -1.68 & \\
\hline
\end{tabular}

Source: Dhaka Stock Exchange. $\quad w w w . d s e b d . o r g /$ 
From the table-3, the total issued capital of share is Tk.216487 million in 2010 and the market capitalization of share is Tk. 3001334 million in 2010. The average growth rate of issued capital and market capitalization of share are 25.49 percent, 71.02 percent respectively. The average percentage of share to total market capitalization is 87.72 percent. The growth rates of percentage of share to total market capitalization are $8.18 \%$, $6.24 \%$ in the year 2010,2009 respectively but average growth is $-1.679 \%$.

5.2.3 Growth and Development of Mutual Fund

Table 4. Development of mutual fund

\begin{tabular}{|c|c|c|c|c|c|c|c|c|c|c|c|c|c|c|}
\hline 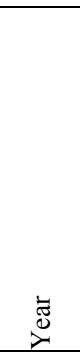 & 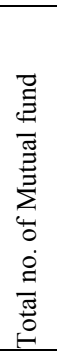 & 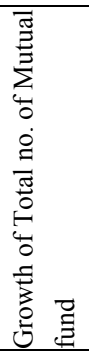 & 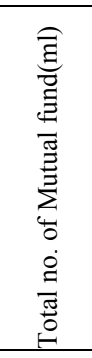 & 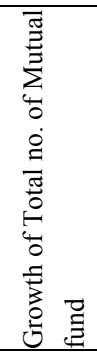 & 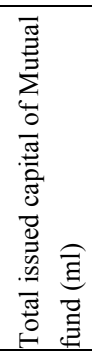 & 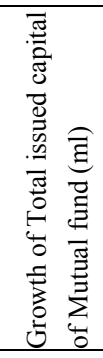 & 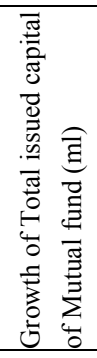 & 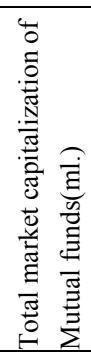 & 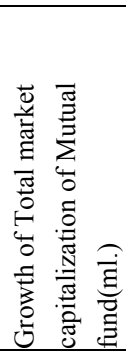 & 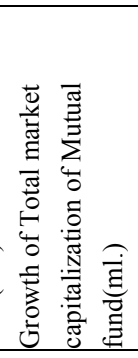 & 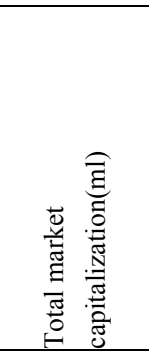 & 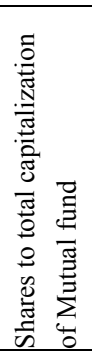 & 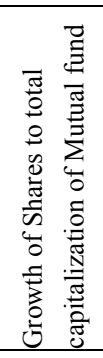 & 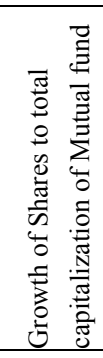 \\
\hline & & & & & & $\begin{array}{l}\text { base } \\
\text { year }\end{array}$ & $\begin{array}{l}\text { year to } \\
\text { year }\end{array}$ & & $\begin{array}{l}\text { base } \\
\text { year }\end{array}$ & $\begin{array}{c}\text { year to } \\
\text { year }\end{array}$ & & & $\begin{array}{l}\text { year to } \\
\text { year }\end{array}$ & $\begin{array}{l}\text { base } \\
\text { year }\end{array}$ \\
\hline 2003 & 11 & & 73.25 & & 395 & 2003 & growth & 663.6 & 2003 & growth & 97586.61 & 0.68 & growth & 2003 \\
\hline 2004 & 11 & 0 & 73.25 & 0 & 395 & 0 & 0 & 1046.2 & 57.66 & 57.66 & 224922.74 & 0.47 & -21.49 & -31.60 \\
\hline 2005 & 13 & 18.18 & 161.25 & 120.14 & 735 & 86.08 & 86.08 & 1521.4 & 129.26 & 45.42 & 233542.94 & 0.65 & 18.63 & 2639.75 \\
\hline 2006 & 13 & 0 & 161.25 & 0 & 735 & 86.08 & 0 & 1537 & 131.62 & 1.03 & 323368.00 & 0.48 & -17.61 & -30.10 \\
\hline 2007 & 14 & 7.69 & 190 & 17.83 & 866 & 119.24 & 17.82 & 5232 & 688.43 & 240.40 & 753955.00 & 0.69 & 21.86 & 3115.10 \\
\hline 2008 & 16 & 14.29 & 325 & 71.05 & 3116 & 688.86 & 259.82 & 15778 & 2277.64 & 201.57 & 1059530.00 & 1.49 & 79.52 & 118.99 \\
\hline 2009 & 19 & 18.75 & 450 & 38.46 & 4816 & 1119.24 & 54.56 & 18064 & 2622.12 & 14.49 & 1887177.00 & 0.96 & -53.20 & 40.76 \\
\hline 2010 & 31 & 63.16 & 2075 & 361.11 & 21066 & 5233.16 & 337.42 & 43064 & 6389.45 & 138.40 & 3471109.00 & 1.24 & 28.34 & 82.44 \\
\hline $\mathrm{x}$ & & & & & & & 107.96 & & & 99.85 & & 0.83 & 8.01 & \\
\hline
\end{tabular}

Source: Dhaka Stock Exchange. $\quad$ www.dsebd.org/

From the table-4, the total issued capital of Mutual fund is Tk.21066 million in 2010 and the market capitalization of Mutual fund is Tk. 43064 million in 2010. The average growth rate of issued capital and market capitalization of Mutual fund are 107.96 percent, 99.85 percent respectively. The average percentage of Mutual fund to total market capitalization is 0.83 percent. The growth rate of percentage of Mutual fund to total market capitalization is $8.01 \%$.

\subsection{Comparative Share of Products to Total Market Capitalization}

The comparative share of products to total market capitalization is presented in figure 1 .

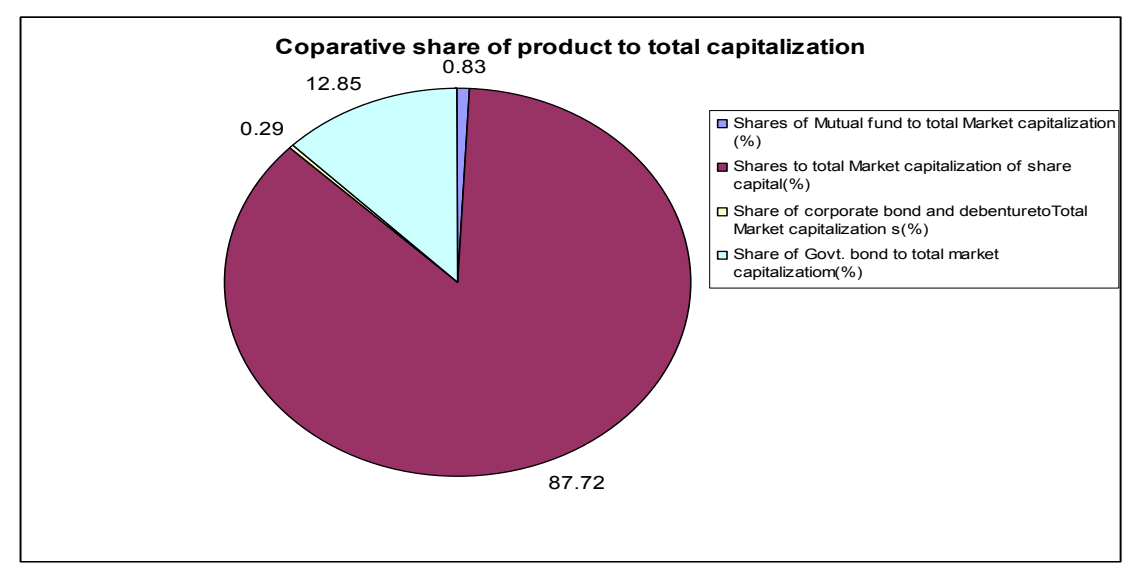

Figure 3. Comparative share of products to market capitalization 
The average share of corporate bond \&debentures and government Treasury bond, Share capital, mutual funds to total market capitalization are $0.29 \%$ and $12.85 \%, 87.72 \%, 0.83 \%$ respectively. The contribution of mutual fund, corporate bond and debenture are not significant. The market is mainly share capital based. Now, the growth rates of products are compared with t-test.

\subsection{Hypothesis test-1}

Ho.: There are no differences of the growth rates among the financial products.

Table 5. Paired samples test

\begin{tabular}{|c|c|c|c|c|c|c|c|c|c|}
\hline & & \multicolumn{5}{|c|}{ Paired Differences } & \multirow[t]{2}{*}{$\mathrm{t}$} & \multirow[t]{2}{*}{ df } & \multirow{2}{*}{$\begin{array}{c}\text { Sig. } \\
\text { (2-tailed) }\end{array}$} \\
\hline & & Mean & $\begin{array}{c}\text { Std. } \\
\text { Deviation }\end{array}$ & $\begin{array}{l}\text { Std. } \\
\text { Error } \\
\text { Mean }\end{array}$ & $\begin{array}{r}95 \% \text { Con } \\
\text { Interval } \\
\text { Differ }\end{array}$ & $\begin{array}{l}\text { fidence } \\
\text { of the } \\
\text { ence }\end{array}$ & & & \\
\hline Pair 1 & $\begin{array}{l}\text { Growth of market capitalization of } \\
\text { share - Growth of market capitalization } \\
\text { of mutual fund }\end{array}$ & -871.49 & 1281.72 & 484.44 & $\begin{array}{c}\text { Lower } \\
-2056.89\end{array}$ & $\begin{array}{c}\text { Upper } \\
313.89\end{array}$ & -1.799 & 6 & .122 \\
\hline Pair 2 & $\begin{array}{l}\text { Growth of market capitalization of } \\
\text { share - Growth of market capitalization } \\
\text { of treasury bond }\end{array}$ & -766.81 & 601.91 & 269.18 & -1514.19 & -19.43 & -2.849 & 4 & .046 \\
\hline Pair 3 & $\begin{array}{l}\text { Growth of market capitalization of } \\
\text { share - Growth of market capitalization } \\
\text { of corporate bond and debentures }\end{array}$ & 493.88 & 843.58 & 318.84 & -286.30 & 1274.07 & 1.549 & 6 & .172 \\
\hline Pair 4 & $\begin{array}{l}\text { Growth of market capitalization of } \\
\text { mutual fund - Growth of market } \\
\text { capitalization of treasury bond }\end{array}$ & 467.84 & 1351.76 & 604.52 & -1210.59 & 2146.28 & .774 & 4 & .482 \\
\hline Pair 5 & $\begin{array}{l}\text { Growth of market capitalization of } \\
\text { mutual fund - Growth of market } \\
\text { capitalization of corporate bond and } \\
\text { debentures }\end{array}$ & 1365.38 & 2071.03 & 782.77 & -550.00 & 3280.77 & 1.744 & 6 & .132 \\
\hline Pair 6 & $\begin{array}{l}\text { Growth of market capitalization of } \\
\text { treasury bond - Growth of market } \\
\text { capitalization of corporate bond and } \\
\text { debentures }\end{array}$ & 1408.55 & 1197.84 & 535.69 & -78.76 & 2895.87 & 2.629 & 4 & .058 \\
\hline
\end{tabular}

From the table 5, it is seen that the calculated value of $t$ for the pairs 2 and 6 are $-2.84,2.62$ respectively which are greater than the table value (2.13) of $\mathrm{t}$ at $5 \%$ significance level. It means that the differences are significant. So, the growth of market capitalization of Treasury bond is more than the growth rate of capitalization of share and corporate bond and debenture.

From the table -5 , it is also observed that the calculated value of $t$ of pairs $1,3,4,5$ are lower than the table value (1.94). So, the differences are not significant. So, there are no significant difference between the growth rates of market capitalization of share and mutual fund, share and corporate bond, mutual fund and corporate bond.

Finally, it is said that the growth rate of government bond is more and significant.

\section{Product Market Development and Recommended Strategies}

The percentage of average market capitalization of common stock, mutual fund, Treasury bond and corporate bond are $87.72 \%, 0.83 \%, 12.85 \%, 0.29 \%$. So, the operation of market is totally share oriented. Therefore, any distortion or falling of share price causes the destruction of capital market.

The growth of market capitalization of government bond is more than share and corporate bond but it is traded in over the counter market and within the institutional investors and it is beyond the individual investors. The corporate bond market is not significant in terms of size. So, there should be increased new financial instruments and corporate bond in the market to reduce the dependency on share only.

The proposed financial instruments are various types of bond, SWAP, Option, Futures.

Bond: There are lots of scopes to develop the bond market with various features like dual currency bond, convertible bond, and income bond. 
SWAP: Like the developed market, the SWAP will be introduced to minimize the risk of dependency on share capital only. The currency swap, commodity swap, interest rate swap will be effective.

Option: The derivatives instruments are the vital products in the capital markets. The Chittagong Stock Exchange proposed to SEC for introducing derivatives products but it is not implemented yet. There is a large field of financial products in this area such as call option, put option, multi period option, spread, and straddle.

Futures: it is a derivative product with a feature of depending on any fundamental products which will enrich the capital market of Bangladesh.

Preferred stocks: Characteristics of preferred stock is specified between the common stock and bond.

\section{Conclusion}

The performance of existing financial products is an important issue in the capital market to increase the new products for reducing the risk of dependency on common stocks. There are only five products are traded including three types of bonds. The average growth rate of market capitalization of common stocks, treasury bonds, mutual funds, corporate bonds \& debentures are $71.02 \%, 124.74 \%, 99.85 \%$ and $105.41 \%$ respectively. The growth of market capitalization of all products is high. The share of common stocks, treasury bond, corporate bond, debentures, mutual funds to total market capitalizations are $87.73 \%, 12.25 \%, 0.24 \%, 0.17 \%$ and $0.83 \%$ respectively. So, the market is common stock based. The government bonds are traded among the institutional investors. The corporate bond market is very small. There is lot of scope in the market for absorbing the new products. So, there should be increased new financial instruments in the capital market to reduce the dependency on share only. The proposed financial instruments are various types of preferred stock, bond, SWAP, option, futures, and forwards. There are lots of research scopes in this field to study the products which will be effective for this market.

\section{References}

Ahmad, Zahid et al. (2012). Stock market development and economic growth: A comparative study of Pakistan and Bangladesh. African Journal of Business Management, 6(8), 2985-2989. Retrieved from http://www.academicjournals.org/AJBM

B., McGuire Paul \& John, D. Conroy. (2004). Fostering Financial Innovation for the poor. FDC. Retrieved from jbao.atu.edu/Fall2008/Bepari,\%20Mollik.doc

Chaudhury, M., \& Miyan Allimullah. (2010). Development of Capital Market in Bangladesh. Retrieved from http://people.mcgill.ca/files/mohammed.chaudhury/CapMarketsBD.pdf

Chittagong Stock Exchange Ltd. (2004). CSE-30 Company Profile. Chittagong: CSE.

Dhaka Stock Exchange. (2011). Monthly Review, 26(5). Dhaka, Bangladesh: Dhaka Stock Exchange Limited.

Fabella, R., \& Madhur, S. (2003). Bond Market Development in East Asia: Issues and Challenges. Asian Development Bank, Manila: ADB.

Finance Ministry. (2011). Bangladesh Economic Review-2010. Dhaka: Economic Wing.

International Organization of Securities Commissions. (2002). The Development of Corporate Bond Markets in Emerging Market Countries. May, USA.

Jahur, M. S. (2009). Development of Bond Market in Bangladesh: Issues, Status and Policies. Portfolio, 3, JulySeptember. Chittagong: Chittagong Stock Exchange.

Kothari, C. R. (2005). Research Methodology. New Delhi, India: New age International pvt. Ltd.

Levine, Ross \& Sara Zervos. (2012). Stock Markets, Banks, and Economic Growth. The American Economic Review, 88(3), 537-558.

Marshall John, F., \& Vipul, K. Bansal. (2003). Financial Engineering. New Delhi,India: Prentice Hall of India Pvt. Ltd.

Mu, Yibin. (2007). South Asia Bond Markets and Bangladesh. World Bank, Dhaka.

Mukherjee, A., \& Faruqe, G. (2009). Capital Market In Bangladesh-Trend sand Practices, Bangladesh.

Rashid, M. (2008). The Potential of the Bangladesh Capital Market. Monthly Review, The Daily Star, 3(5), May.

Securities and Exchange Commission. (2011). Annual Report 2009-10. Dhaka, Bangladesh. 
Rahman, Md. Tariqur \& Khondker Golam Moazzem. (2011). Capital Market of Bangladesh: Volatility in the Dhaka Stock Exchange (DSE) and Role of Regulators. International Journal of Business and Management, 6(7). http://dx.doi.org/10.5539/ijbm.v6n7p86

The Annual Report. (2005/2006/2007/2008). Bangladesh Bank, Dhaka, Bangladesh.

World Bank. (2003). Improving the Investment Climate in Bangladesh. Washington. Retrieved from http://www.undp.org/ods/publications.html

Yewar, S. (2005). Debt Market in Bangladesh-Problems and Prospects. Paper Presented in the National Conference, AIMS, Dhaka. 